\title{
Cross-Cultural Encounters, Self-Estrangement and Mutual Understanding in Tayeb Salih's Season of Migration to the North
}

\author{
Mohammad Jamshed \\ Assistant Professor, English, College of Business Administration, Prince Sattam bin \\ Abdulaziz University, Al-Kharj, Kingdom of Saudi Arabia. \\ Email: jamshed.psau.edu.sa@gmail.com
}

\begin{abstract}
Cross-cultural encounters and confrontations constitute major areas of postcolonial studies. These depictions are built upon a few stereotypes, colonial constructs and 'exotic' images of people. Even in this globalized world of today, these problematic and false assumptions continue directing our ways of thinking and understanding. We are deeply either ill-informed or misinformed about people who are like us with an insignificant difference in culture and language. As a result, the increasing cultural divide, tensions, conflicts, and misconceptions plague collective human existence. The postcolonial writings, travel literature and feminist studies, characterized by the ideas of 'self and 'other', serve as the theoretical framework for this study. These theories have strong parallels as they seek to empower the oppressed and reinstate the marginalized to the position of equality and dignity. The paper attempts to examine in brief how African and Arab writers of the twentieth century, spurred to write back to their demonization in western literary texts, instead chose to promote cultural understanding and present their story from their cultural perspectives. With the help of textual analysis and Fanon's Black Skin, White Masks, the paper shows how this colonial trauma distorts perspectives and engenders a sense of self-estrangement and rootlessness which adversely affects the personal lives of people. The paper seeks to use this study to dismantle the stereotypes, reveal similar urges and passions to move away from a troubling past towards a future of mutual respect and cultural understanding. Thus, free from all these mistaken notions misdirecting our ways of dialogues and communications, we, as a global community, will get rid of the ills plaguing our existence across cultures and regions.
\end{abstract}

Keywords: colonialism; stereotypes; estrangement; cross cultural encounters; understanding; distortions

\section{Introduction}

The issues of representation and cross-cultural engagements are dominant themes in postcolonial writings. These studies are primarily concerned with examining the colonial history from the perspective of the colonized people and nations. They study the process of decolonization "and cultural impact of colonialism on both the colonized peoples and the colonizing powers" (Habib 2005:739). Much of the postcolonial discourse is informed by theories that include the politics of representation and the process of 'othering'. Building upon the philosophical works of Hegel and others, Fanon argues that the cultural representations of Black people are made in ways that make them look more animalistic and less human. According to him, colonialism "turns to the past of the oppressed people, and distorts, disfigures and destroys it. This work of devaluing pre-colonial history takes on a dialectical significance today" (Fanon 2001:169). They are depicted as bodies

(C) AesthetixMS 2020. This Open Access article is published under a Creative Commons Attribution Non-Commercial 4.o International License (http://creativecommons.org/licenses/by-nc/4.o/), which permits non-commercial re-use, distribution, and reproduction in any medium, provided the original work is properly cited. For citation use the DOI. For commercial re-use, please contact editor@rupkatha.com. 
rather than people with mind and feelings. Edward Saeed's seminal text Orientalism (1978) demystifies how the process of othering is constructed and conceptualized in western literary texts. His Orientalism shows how the West has a long history of deliberately misrepresenting the Arab world and the Middle East primarily for colonial reasons. For example, the Europeans have a habit of associating the people from Africa and the Middle East with baser traits of illiteracy, savagery, and superstitions. They have been a source of continuing interest for Europeans even before this idea of colonialism and imperialism as means of territorial control came into existence. On the one hand, the Europeans talk of educating and civilizing these people plagued by illiteracy and poverty; on the other hand, they oppress them and treat them like animals.

Widely regarded as a counter-narrative to texts like Joseph Conrad's Heart of Darkness (1902) and Joyce Cary's Mister Johnson (1939), Season of Migration to the North (1966) is considered one of the most important novels of the twentieth-century Arab literature. Edward Said described it as one of the great six novels in Arabic literature. Thematically, the novel bears a close resemblance to Fanon's Black Skin, White Masks (1952) as they both extensively deal with the 'politics of desire' between white women and black men. The text is often seen as part of African writers' efforts to respond to centuries of misrepresentations and inhuman portrayal of Africans in European writings. With the Eurocentric view being increasingly challenged, "nonwestern cultures and societies are an increasingly active participant in shaping the future of the world." (Dallmayr 1996:9). The authors from postcolonial societies chose to respond to the centuries of misrepresentations and speak the story of their side from their perspectives. In the early fifties and sixties, writers like Chinua Achebe, Ngũgĩ wa Thiong'o, Wole Soyinka, Abdulrazak Gurnah and Tayeb Salih wrote to chronicle postcolonial history and counter the negative African portrayals in European literary discourse.

Postcolonialism and feminist theory, with strong parallels in terms of the issues of 'self and 'other', the themes of marginalization and empowerment, serve as a theoretical framework for the current study. The paper attempts to conduct a study in unfolding cross-cultural encounters, confrontations, and cultural understandings. The study builds upon both these theories as they both "seek to reinstate the marginalized in the face of the dominant" (Ashcroft et al. 1989:173). The paper further examines, with the help of Fanon's Black Skin, White Masks, twists and distortions in the perspectives of people and how deliberate distortions and the trauma of colonialism engenders the sense of self-estrangement in people across cultures and regions. The paper deals, in brief, with the corrosive effects of this alienation in the personal and intimate relationships of individuals. In the last, the research presents how the author encourages people to discard false notions and look at each other as individuals rather than as representatives of cultures for cultural understanding and harmonious existence.

\section{Literature Review}

While European literacy writings have always tended to misrepresent Africans and the Arab world, the debate around these exotic and false assumptions in the twentieth century was triggered by Joseph Conrad's Heart of Darkness (1902) and Joyce Cary's Mister Johnson (1939). Time Magazine described Mister Johnson as the best book about Africa but Chinua Achebe had it differently. Deeply moved by its depictions of Africa and its people, he chose to respond to this colonial stereotyping from an African perspective with his magnum opus Things Fall Apart (1958). Mister Johnson, Achebe says in Home and Exile (2000), opened his eyes to the demonized and problematic images of African and his people. After some time, Achebe was convinced that Mister Johnson was one just one from a long list of books that had deliberate negative portrayals of Africa 
and the Middle East. He concluded with the hope that his writing would put a true picture of his people resulting in the balance of stories. This present study uses recent work of scholars from Africa, the Arab world and the Middle East who have in recent past looked at these cross-cultural engagements and images of 'self' and 'other in both western and Arab literature. They foreground the contradictory attitudes and demonstrate how these texts perpetuate the exotic images and stenotypes of the Africans. These works provide a fresh perspective to raging debates around issues of cultural engagements and representations.

Fred Dallmayr's Beyond Orientalism: Essays on Cross-cultural Encounter (1996) examines the issues of otherness and difference from the perspective of contemporary western philosophy. This study uses the notion of deconstructive dialogues and hermeneutics of difference to promote the cause of respect for others beyond cultural assimilation. Rasheed El- Enany's Arab Representations of the Occident: East-West Encounter in Arabic Fiction (2004) examines western culture from a fresh Arab perspective, condemns the contradictory attitudes and examines the ways African and Arab intellectuals chose to respond to the centuries of negative depictions. But its coverage of a long period of two centuries makes it look more of historical work and less literary work. Hans Gullestrup's Cultural Analysis: Towards Cross-cultural Understanding (2006) provides a fresh perspective into an understanding of cultural differences. With globalization, the book contends, the world is reduced to a global village and the issue of cross-cultural encounters and dialogues has become a daily routine. This social and cultural interaction and collaboration enable people and cultures to dispel long-held misconceptions and facilitate a better understanding and fruitful communication.

Tanja Stampfl's A Century of Encounters: Writing the Other in Arab North Africa (2019) deals with specific patterns of encounters, confrontations, the issues of cultural misunderstandings and how these dialogues and communications challenge our existing false of self and other. The book lays special emphasis on how these encounters help us question our current understanding of people and cultures. The study uses encounters and cross-cultural representations as lenses to understand the contemporary world and comparative literature. These studies provide newer insights into existing knowledge in general. These works, however, are general and do not adequately foreground the message of peace and harmonious existence from African and Arab authors who themselves are victims of demonization in literary discourse. The present paper builds upon all this scholarship to carry forward the cross-cultural discourse, unfolding patterns of these encounters, and the efforts of peace and reconciliation by these authors with special reference to Season of Migration to North.

\section{Theoretical Framework}

The postcolonial authors denounce the ethnocentric and Eurocentric perspective of their countries and present a counter-narrative and a true picture of theirs based on truth and reality. They respond to misconceptions in western literary discourse. Edward Said's Orientalism (1978) which builds on Foucault's insights, is now a central text for postcolonial studies and crosscultural confrontations. According to the author, Orientalism that primarily took roots in Europe is the discourse about the Arabs world and the Middle East. In his opinion, this notion of Orientalism created the Orient to serve in the imagination of the West as the colonized and inferior other. The West often views the Middle East and Asia with prejudice and the lens of racism. This kind of imperialism imposed in subjugated colonies "a Eurocentric discourse that assumed the normality and pre-eminence of everything occidental" (Abrams 237). This exotic 
image is the deliberate creation of Europe to satisfy the imperial agenda. These societies are presented as static and underdeveloped for legitimizing their patronization, economic control, and colonization of these societies.

Postcolonialism, feminist and psychoanalysis studies serve as a theoretical framework for this study. These theories have strong parallels as they are concerned with the issues of marginalization, empowerment and the trauma of colonization and estranged existence. They seek to empower the oppressed and reinstate him/her in the position of power and to the status of equality. With the help of psychoanalysis, the study shows the traumatic experience of the characters, the loss of identity, rootlessness and decodes "the germs of deadly disease" ruining the relationships of all female characters. The research paper employs these theories to survey crosscultural patterns, corrosive effects of the colonial trauma on people, distortions it creates and the sense of estrangement it engenders in people.

Besides various unknown sources, three known sources can be accounted from where Europe developed an image of the East: Crusader Wars, Orientalism and Arabian Nights whose tales were widely circulated in Europe as the interest in the Arab world increased. The large body of the travel literature in nineteenth-century literature also contributed to the West developing an image of Africa and the Arab world from these travel accounts. "European discourses about Africans make it clear that such functionalism is inadequate because even before the actual enslavement and colonial plunder of Africans began, racist stereotypes which were obsessed with color and nakedness were well in place" (Loomba 2005:113). The majority of literary works from the West from Chaucer to the present day view a man from the Middle East as exotic and 'Other' who is less capable than any man in the West. The Knight's Tale in Chaucer's Canterbury Tales (1476) celebrates the prowess and courage of Christian knight for his bravery to confront and resist the Muslim warriors in the East. They always tend to associate Easterners with baser instincts and traits. Instead of being viewed as individuals with noble traits of reason, logic and rationality, they are often seen as class whose actions are guided by outbursts and instinctive emotions like lust, impulse and anger.

\section{Discussion and Analysis}

The term 'encounter' involves a meeting of two different persons and cultures. Unlike meetings, encounters question our beliefs, provide us fresh perspectives and new insights into things and people. Through this process, one's existing beliefs and opinions are challenged and reshaped. An encounter and engagement, according to Stampfl, affirm our existing constructions and challenges and questions them as well. In our daily life, we are constantly in the process of negotiations and interactions which help us categorize these cultural confrontations. For these notions to undergo any significant change, we need to look beyond our zones of comforts, give a patient hearing to the contrary views and recognize others as equal fellow beings. "Someone committed to a racist identity, for example, may begin to question and even reject racist notions after having engaged in a transformational encounter with someone who did not share the racist views" (Stampfl paras. 4). Literature offers us an opportunity to look back at these events and encounters to evaluate and analyze the existing constructions and conceptualizations in literary texts. Viewed from this perspective, we find some established and unfolding patterns in literary texts.

\subsection{Cross-Cultural Encounters and Experiences}


If one is to compare and contrast the texts from Africa and the Arab world with the ones from Europe, one finds an interesting and definite pattern. The hero's journey's to Europe in African literature of the twentieth-century is often community-oriented and self-fulfilling as the traveling has a clearly defined aim of self-enlightenment. These characters from the Middle East are shown journeying to Europe for enlightenment and they return with a clear aim of developing and uplifting their societies. The western literary texts show the characters as an enlightened mind with a degree of perfection who journey to Africa and the Middle East with a declared mission of educating and civilizing people. "Modern Europe sees itself as the product of the Enlightenment, with the attending ideals of reason, freedom, liberty, equality, progress and the rule of law" (Mahmud 1999:1219). The motive behind such delineations has always been asserting racial superiority and legitimizing the territorial control. Widespread educational reforms, the teaching of European languages, history, and culture to the native people had the desired effect: a whole generation of Africa grew up with such disturbing and problematic self-images. Robinsons in the text and Richards amply illustrate the colonial mission. This theme is underscored when Mustafa Saeed talks of a riding man in uniform on the back of a horse and asking him if he wanted to study.

When such encounters occur, the native people react to them in a variety of ways. They are suddenly caught between resisting and embracing the change they are not psychologically prepared to accept. They face the immediate dilemma of determining how well to adapt to this reality of an urgent change. The first encounter at the very beginning of the novel makes it clear that general feelings towards colonizers in his native village were like those found in other colonized countries. These colonizers were thought of as evils and forces of occupation which posed a threat to their culture, religion, and tradition. "The white man is very clever. He came quietly and peaceably with his religion. We were amused at his foolishness and allowed him to stay. Now he has won our brothers, and our clan can no longer act like one. He has put a knife on the things that held us together and we have fallen apart" (Achebe 1994:161). These colonizers, in the opinion of the locals, sowed seeds of discord among the native people. Mamur, a retired public servant, speaks to the narrator how the colonizers had torn apart their social fabric by sowing the seeds of hatred among their brethren. The result was that the native people considered schools as being "a great evil that had come to them with the armies of occupation" (Salih 2003:20). The local people viewed this colonial engagement from the perspective of conquest and exploitation as is clear from what Mustafa Saeed's words at the very beginning.

The schools were started to teach us how to say "Yes" in their language. They imported to us the germ of the greatest European violence as seen on the Somme and at Verdun, the like of which the world has never previously known, the germ of the deadly disease that struck them more than a thousand years ago (Salih 2003:95)

The cultural engagement in the text occurs at both individual and societal levels, and they play out differently in different contexts. For example, Robinsons, familiar with Islamic culture and architecture, do not view Mustafa Saeed from colonial lens and stereotypes. "Mr. Saeed, you 're a person quite devoid of a sense of fun, can't you ever forget your intellect" (Salih 2003:25), says Mrs. Robinson to Mustafa Saeed. Robinsons are so fond of him that they wait for him at the railway station. They enjoy very close and cordial relationships with him. On the other hand, Mustafa Saeed's relationship with his fiancés in England is marked by an extreme level of physical violence. His comment that he would liberate Africa with the power of his penis alludes to the idea of symbolic rape and his desire of using his romance to avenge colonial excesses to his people. His encounter with these women turns their lives upside down. They are romantically 
involved with him but their relationship is marred by unending conflict and mental agony. His remarks during his trials that he was a "colonizer" speaks of his deep-rooted desire to occupy the position of his colonial masters. He subjugates these women to satisfy his revenge instincts. This proxy of colonialism and the following consequences reverberate through the relationships of individuals. A further look at these individual relationships will help explore the theme.

The most interesting encounter which is symbolic of colonial devastations is between Jean Morris and Mustafa Saeed. Their relationship was marked by violence and physical assaults. She taunted him for his failure to carry out acts of violence. What becomes evident here is a certain degree of affinity and desire for death and destruction in her character. This unexpressed wish of her for death is "the germ of deadly disease" which professor Maxwell refers to while arguing for the defense of Mustafa Saeed. Mustafa Saeed attempts to control and subjugate her. He says that "a volcano of violence would explode within her and she would break any crockery that came to hand and tear up books and papers" (Salih 2003:160). He time and again equates himself with a pirate sailor and invader and Morris Jeans with destruction. His viewing himself as an invader in his relationships makes clear that he did not look up for a relationship beyond victimizing these women to satisfy his colonial instincts. He views Jean's murder in terms of reverse colonialism and conquest. Unlike Isabella Seymor, Ann Hammond and Sheila Greenwood, she was not interested in his African roots. And this partly explains why Mustafa was unable to manipulate her and subject her to physical violence.

Unlike Jean Morris, other women viewed him from colonial perspectives that echoed and evoked the images of the "other". For Ann Hammond, Mustafa Saeed was a symbol of "tropical climes, cruel suns, purple horizons" (Salih 2003:142). She understood and looked at him through stereotypical depictions of his land. These centuries of false depictions shaped not only how European thought of Africans but also how Africans thought of themselves. For her Mustafa "was a symbol of all these hankerings of hers" (Salih2003:142). She gave up her studies to stay with Saeed. She would tell him how it was the smell of "rotting leaves in the jungles of Africa, the smell of the mango and the pawpaw and tropical spices, the smell of rains in the deserts of Arabia" (Salih2003:142). Saeed used to quote Arabic poetry to her. She used to tell him that she could see deserts in his eyes. He used to take her to his Oriental London apartment where she used to play his slave girl and he did her master. One day she was found dead leaving a note wherein she wrote, "Mr. Saeed, God damn you!" The play-acting reproduces and recreates the reversed order of colonial oppressions wherein he becomes the master and she did the slave. This colonial oppression "dislocates and distorts the psyche of the oppressed" (Loomba 2005:122). Hammond's comments reveal how these stenotypes lead people to view each other in reductive and essentialist ways that signal to the dynamics of colonialism in interpersonal settings. This is what Fanon refers to when he says that colonialism dehumanizes both the colonizer and colonized alike.

The relationship between Mustafa Saeed and Isabella Seymor offers another instance of cross-cultural experiences. Isabella Seymor "was the wife of a successful surgeon and the mother of two daughters. She had elven years of happy married life" (Salih 2003:140). One day she professed her deep love to Saeed. "Ravish me, you African demon. Burn me in the fire of your temple, you black god. Let me twist and turn in your wild and impassioned rites (Salih 2003:106). After a short relationship, she, however, commits suicide. What is surprising here is Seymor's wishing Saeed a happy life and her husband's confession during the trial that his wife had cancer before her death. He rejects the prosecution's charges that she died due to the emotional manipulation of Saeed. He says that "all through her life with me she had been the model of a 
true and faithful wife. Despite everything, I feel no bitterness within myself, neither against her nor against the accused. I merely feel a deep sadness at losing her" (Salih 2003:141). Her expression of happiness despite the turbulent relationship echoes the same fluctuations Saeed had towards Britain-hailing and hating simultaneously. He likens himself to the Arab soldiers who invaded Spain during the middle ages. He, in this way, is merely reversing the dynamics of the relationship in terms of conquest and oppression.

Sheila Greenwood's relationship with Mustafa Saeed offers yet another example of the colonial encounter. He had "seduced her with presents, honeyed words and an unfaltering way of seeing things as they are" (Salih 2003:139). She was hopeful of class differences coming to an end one day when all people would be brothers. She was aware of the racist ideology pervading her society. At the very beginning of her acquaintance, she told Saeed that her mother would go mad if she became aware of her love for a black man and her father would kill her. Saeed's exotic appearance, color, cultural roots had deeply intrigued her. She told Saeed "your tongue's as crimson as a tropic sunset". She once said to him, "How marvelous your black color is" (Salih 2003:139). She had an idyllic relationship with Saeed but she kills herself as she realizes that he does not intend to marry her. Though Saeed uses stereotypes to perpetuate this cycle of violence against these women, they are not his constructs.

\subsection{Self-Estrangement and Rootlessness}

While offering five major dimensions of estrangement and alienation in the paper On the Meaning of Alienation (1959), Melvin Seeman defines self-estrangement as a detachment between one's actual self and his idea of absolute perfection. Without the prefix of 'self, the word 'estrangement' refers to a condition in which man experiences a separation from self and other human beings. To put it simply, "self-estrangement engenders feelings of boredom, passivity, and fatalism" (Silver 1986:30). Though frequently dealt with theme in the literature of all times, the unexpected changes, existential conditions and dogged pursuit of materialism in the twentieth century brought the term to spotlight. Edmund Fuller says, "Man suffers not only from war, persecution and famine and ruin but from inner problems, a conviction of isolation, randomness, and meaninglessness in his very existence" (Fuller 1958:3). The painful experience of selfestrangement manifests itself in different forms-like alienation from self, from an acquaintance and society and people around himself. There seems to be "always a struggle between what the individual aspires for and the harsh reality of what he achieves, what he professes and what he practices, what he really is and what he would like to be taken for." (Tandon 2006:75). This is the manifestations of how the trauma of colonialism engenders acute pain of isolation.

In the text, the protagonist, having got back to Sudan, finds himself fluctuating between his two self-created different worlds. One world is England and the other is the village of Wad Hamid in Sudan where he has just returned. He is unable to reconcile between the 'push' and 'pulls' of these widely two different worlds. And the two rooms in these places contain the mystery of his mysterious existence and strange ways of life. He uses his England room as a tool to exaggerate his exotic origins to trap English women. In the same way, his secret room in Wad Hamid, full of English books, acts as a temple to his English life. His words to the narrator to spare his sons 'wanderlust' speaks of his rootless and estranged existence. This is perhaps the reason for his possible suicide given his continuous yearning for faraway parts. His wish for death and destruction may be interpreted as his ultimate move to find a way out of his rootless and alienated existence. His uninterrupted travels after release from jail, his confession in the letter, 
that wanderlust continues plaguing him even in Wad Hamid, his native place, illustrates the way he was leading an embittered life marked by an ever-increasing emptiness. This disintegration and disorientation marked his life from the very beginning as he never felt deeply connected to anyone including his mother.

She and I acted as relatives to each other. It was as if she were stranger on the road with whom circumstances had chanced to bring me. Perhaps it was I who was an odd creature, or maybe it was my mother who was odd- I don't know. We used not to talk much. (Salih 2003:19)

The narrator's existence also was equally afflicted by this instability of identity. In the early days of his return from London, he feels stabilized and connected to his native roots of Wad Hamid. The people of the village are excited to welcome him back. But he is intrigued by the enigmatic presence of Mustafa Saeed and starts enquiring about him. After a while, he finds himself on the other side of village life. Having defended Hosna after she murdered Wad Rayyes for forced marriage, he increasingly became aware of his ideas and values not aligning with the parochial and misogynistic values of the villagers. The narrator's defense of Hosna brought him in direct conflict with the other villagers. He started feeling increasingly estranged from his people and he painfully realized that Saeed's cultural alienation reflected his loss of identity. This is clear when the narrator makes an entry into this mysterious and restricted room and mistakes his face for Saeed's. This mistaken image speaks of how deeply they were connected by the experience of rootless existence and utter loss of identity. Saeed is finally destroyed by this loss of identity and estranged existence. And the narrator, however, exhibits a will to live and withstands these challenges by escaping the flood.

The devastation and ravaging effect of estrangement caused by the trauma of colonialism is a global phenomenon. This sense of displacement fills a man's existence with an acute sense of alienation. This is what Fanon refers to when he says colonialism twists people's perspective and engenders a sense of estrangement. While arguing for Mustafa Saeed, defense attorney blames the corrosive effects for the breakdown of their relationships marked by violence and physical assaults. He views Mustafa Saeed's experience from a broad historical and colonial narrative. According to him, these British women provoked his anger as they reduced his existence to colonial stereotypes and exotic images. Mustafa Saeed, he argues, came for enlightenment, but western culture disappointed him deeply. The author seems to make an argument for this. This is further corroborated when the narrator says that his "bedroom was a spring-well of sorrow, the germ of a fatal disease. The infection had stricken these women a thousand years ago, but I had stirred up the latent depths of the disease until it had got out of control and had killed" (Salih2003:34).

Thus, the text amply makes it clear how the trauma of colonialism causes estranged existence and loss of identity. These characters find themselves self-estranged even in their relationships. Mustafa Saeed is unable to enjoy his relationships with the British women as he is guided by feelings of revenge to avenge colonial excesses. The women were also estranged in their relationships with their husbands and families and get drawn to Mustafa Saeed to escape their alienated existence and seek fulfillment. But they end up putting premature ends to their lives which shows the corrosive effects of colonialism in the intimate and personal lives of people. Mustafa Saeed was estranged even in his relationship with his wife Hosna who had stayed with him for all these years after his return from England. They had two children yet she was completely unaware of the mystery and secrecy characterizing her husband's existence. She never thought of entering his secret room which contained the secrets of his past life 


\subsection{Counter Discourse and Mutual Understanding}

The truth, according to Michel Foucault, often is nothing more than the outcome of struggle among competing discourses. He contends that every such discourse encounters a counterdiscourse that challenges its legitimacy and veracity. Given the wide range of human opinions, such discourse meets resistance and challenge. Any such discourse which presents a contrary view and argument can be defined as a counter-argument or counter-discourse. The publication of Edward Said's Orientalism (1978) and Fanon's The Wretched of the Earth (1961) provided the much-needed impetus to the counter-discourse to colonial depictions of African people. Besides decentering the intellectual hegemony of the western literary texts, these works played a vital role in dismantling the stereotypes and questioning the imperial agenda of the Western literary discourse. The African writers are primarily concerned with telling their story from their perspective and dispelling this flawed portrayal. "African literature's fundamental engagement is with the colonial presence in Africa, dismantling its dehumanizing assumptions and resisting its pernicious consequences." (Davids 2007 41-2). These African writers seeks to question and change this racism and stereotypes both in literature and practice with an motive of bridging the cultural divide as is clear from the text.

The novel is widely seen as parts of the attempts of African writers to respond to centuries of European writings which had portrayed Africans as people of a dark continent plagued by ignorance, illiteracy, superstitions, and poverty. Like Things Fall Apart, the text aims to respond to these dehumanized images of Africans and the Arab world. Well aware of the tensions and conflicts marking the twentieth century, the author, with the help of the text, seeks to dismantle these racial stereotypes to bridge the existing cultural divide. He brings out similar urges, drives, passions, delights and common concerns that we all as human beings share and participate in. The author emphasizes the fact that the people in the East and West despite differences in culture and language share more than what they differ. There is an implicit condemnation of Mustafa Saeed and other people of Wad Hamid who continue demonizing the West. He brings out similarities, shared urges and delights to make a strong case for his cross-cultural dialogues and reconciliation.

The fact that they came to our land, I know not why, does that mean we should poison our present and future? Sooner or later they leave our country...... The railways, ships, hospitals, factories, and schools will be ours and we'll speak their language without either a sense of guilt or sense gratitude" (Salih 2003:49).

What the narrator says here is in direct contrast to the portrayal of the British as forces of occupation and evil at the beginning of the text. Tayeb Salih presents a story of his people from his perspective without ever resorting to the negative portrayal of the colonizers. He is generous enough even to praise the colonizers for the development they brought to Sudan. As in the abovegiven quote, Mustafa Saeed also talks of the positive role of the British headmaster of the school who arranged a scholarship for him to send him to Cairo where Robinsons helped him immensely to pursue higher studies. "This is a fact in my life: the way chance has placed in my path people who gave me a helping hand at every stage..." (Salih 200:23). Mustafa Saeed got the benefit of British rule as it was under this rule that he got the opportunity to refine his skills and shape his destiny by first moving to Cairo and then to England under the care and supervision of British people. The narrator and Mustafa Saeed, despite antagonism to the British, have an intense sense 
of respect and reverence for the West because of the freedom it gives, the economic prosperity it promises and the opportunity of growth it offers. The main travel motif of these two characters to the West is the education.

The author, however, does not keep away from speaking the bitter truth. He critiques the colonizers for the contradictions and discriminatory attitudes to Africans. On the one hand, these Europeans mythologize easterners through art and literature. On the other, they use for them the terms and stereotypes which is a complete distortion of reality and speak of their deep-rooted racism. The narrator says that "just because a man has been created on the Equator some mad people regard him as a slave, others as a god." (Salih 2003:89) They consider them animals, colonize their countries, destroy their culture and tradition. They look at them with a sense of contempt and humiliation. The narrator says, "where lies the mean? Where the middle way?" (Salih 2003:89) He emphasizes the need to treat and consider easterners as equal fellow human beings. Some westerners like Robinsons either always romanticize the eastern culture and people like Richard always dehumanizes them. Jean Morris scorns and insults Mustafa Saeed while Isabella Seymor idealizes and idolizes him. Such contradictory views are spoiling the relationships of all these characters. The author champions the middle path in both the personal and political relationships.

Just like us [the Europeans] are born and die, and in the journey from the cradle to the grave they dream dreams some of which come true and some of which are frustrated; that they fear the unknown, search for love and seek contentment in wife and child; that some are strong and some are weak... (Salih2003:3)

\section{Conclusion}

The research paper discussed, in brief, the issues of colonial encounters and confrontations with special reference to Africa and England. With the help of the text, the study shows how the western discourse perpetuated exotic images of the Africans and Arab worlds long before the physical control of these territories. The unfolding patterns of cross-cultural encounters, the racial stereotypes, western contradictory attitudes towards easterners and distortion of perspectives have been dealt with in the study. The study further discussed the senses of estrangement and psychological devastations caused by the trauma of colonialism and how adversely they affect the personal relationships of people across cultures and regions. In the last, the paper concludes with a brief discussion of the response of African writers particularly that of Tayeb Salih to this demonization and the message of peace they give for cultural understanding and peaceful coexistence amid rising tensions and conflicts threatening global peace.

\section{Acknowledgments:}

The author would like to acknowledge the assistance provided by the Deanship of Scientific Research, Prince Sattam Bin Abdulaziz University, Alkharj, Saudi Arabia.

\section{References:}

Abrams, M.H. (2011). A Glossary of Literary Terms. Cengage Learning India Private Limited.

Achebe, Chinua. (1994). Things Fall Apart. Anchor Books.

Al-Enany, Rasheed. (2006). Arab Representations of the Occident: East-West Encounters in Arabic Fiction. Routledge. 
Ashcroft, Bill et al. (1989) The Empire Writes Back: Theory and Practice in post-colonial literatures. Routledge.

Dallmayr, Fred. (1996). Beyond Orientalism: Essays on Cross-Cultural Encounter. State University of New York Press.

Kehinde, Ayo. (2002) Post-Colonial Literatures as Counter Discourse: JM Coetzee's Foe and the Reworking of the Canon. In Pauline Kanene Davids (Ed.), Opuliche: A Story of Courage and Triumph (pp. 33-57). Lulu.com.

Fanon, Frantz. (2007). The Black Skin, White Mask. Grove Press.

Fanon, Frantz. (2001). The Wretched of the Earth. Penguin Books.

Fuller, Edmund. (1958). Man in Modern Fiction. Penguin Random House.

Habib, M.AR. (2005). A History of Literary Criticism from Plato to the Present. Blackwell Publishing

Loomba, Ania. (2005). Colonialism/Postcolonialism. Routledge.

Mahmud, Tayyab.(1999). Colonialism and Modern Constructions of Race: A Preliminary Inquiry. University of Miami Law Review. 53, 1219-1246.

https://digitalcommons.law.seattleu.edu/faculty/501

Morrison, S. A. (1970). Islam and the West. In Lutfiyya, A.M \& Churchill, C.W(Eds.) Readings in Arab Middle Eastern Societies and Cultures (253-258). The Hague: Mouton.

Muhammad Ahmed, E. A. (2010). East Meets West: Gender and Cultural Difference in the Work of Ahdaf Soueif, Farhana Sheikh and Monica Ali. Cardiff University.

Payne, M., \& Barberra J. R . (2010). A Dictionary of Cultural and Critical Theory. Blackwell Publishing

Said, Edward. (2001). Orientalism. Penguin Books.

Silver, M. L. (1986). Under Construction: Work and Alienation in the Building Trades. State University of New York Press.

Srivastava, Priya. (2006) Social Alienation in Karnad's Tuglaq. In Neeru Tandon (Ed.), Perspectives and Challenges in Indian-English Drama (pp. 74-83). Publishers \& Distributors.

Stampfl, Tanja. (2019). A Century of Encounters: Writing the Other in Arab North Africa. Taylor \& Francis Ltd.

Chrisman, L.,\& Williams, P. (Eds) (1993). Colonial Discourse and Post-Colonial Theory. Cambridge: Wheatsheaf.

Salih, Tayeb. (1966). Season of Migration to the North. Retrieved from

https://www.litcharts.com/lit/season-of-migration-to-the-north/summary

Salih, Tayeb. (1966). Season of Migration to the North. Retrieved from

https://www.gradesaver.com/season-of-migration-to-the-north

Mohammad Jamshed got his PhD. degree in 2017 from Aligarh Muslim University, Aligarh(INDIA). His área of interest includes postcolonial literature, travel writings, comparative studies, and socio-political and contemporary issues. He is currently working as Assistant Professor, English, College of Business Administration, Prince Sattam bin Abdulaziz University, Al Kharj, 11942, Kingdom of Saudi Arabia. 